\title{
Teaching versus training emotional intelligence
}

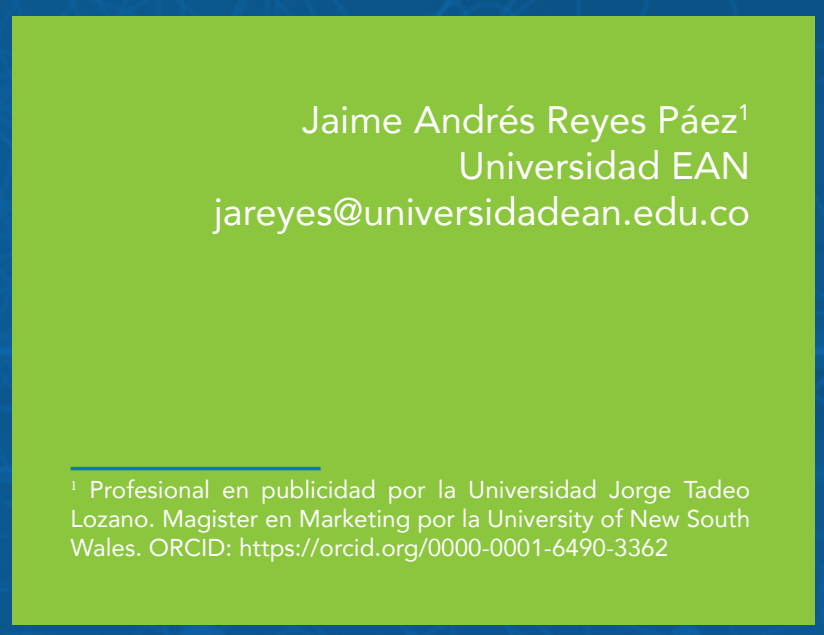

Cómo citar este artículo: Reyes, J. A. (2016). Teaching versus training emotional intelligence. Revista Virtualmente, $4(2), 56-65$. 


\section{ABSTRACT}

This article presents a review of the concept of emotional intelligence, its short history and its definitions. It explores the strengths of the MSCEIT test and highlights some of its weaknesses. The text provides arguments for adopting training as a way to improve emotional intelligence. This perspective is important for leaders and managers of human resources who want to improve their own emotional intelligence and the performance of their teams on this front.

Keywords: emotional intelligence, training, competencies, performance, learning, skills, leadership. 


\section{Enseñanza versus formación de inteligencia emocional}

\section{RESUMEN}

Este artículo presenta una revisión del concepto de inteligencia emocional, su corta historia y sus definiciones. Explora los puntos fuertes de la prueba MSCEIT y destaca algunas de sus debilidades. El texto proporciona argumentos para adoptar la formación como una forma de mejorar la inteligencia emocional. Esta perspectiva es importante para los líderes y administradores de recursos humanos que quieren mejorar su propia inteligencia emocional y el desempeño de sus equipos en este frente.

Palabras clave: inteligencia emocional, capacitación, competencias, desempeño, aprendizaje, capacidades, liderazgo. 


\section{Enseignement versus entrainement de I'intelligence émotionnelle}

\section{RÉSUMẼ}

Cet article offre un récapitulatif du concept d'intelligence émotionnelle, de son histoire, ses définitions et met en évidence les points forts et les faiblesses de l'épreuve MSCEIT. Ce texte fournit également des arguments en faveur d'une formation permettant une amélioration de l'intelligence émotionnelle. Cette perspective est d'importance pour les dirigeants et directeurs des ressources humaines souhaitant améliorer leur intelligence émotionnelle et la performance de leurs équipes.

Mots clefs: intelligence émotionnelle, formation, compétences, performance, apprentissage, capacités, leadership. 


\section{Ensinar versus treinar a inteligência emocional}

\section{RESUMO}

Este artigo apresenta uma revisão do conceito de inteligência emocional, sua curta história e suas definições. Explora os pontos fortes do teste MSCEIT e destaca alguns dos seus pontos fracos. $O$ texto fornece argumentos para adotar a formação como uma maneira de melhorar a inteligência emocional. Esta perspectiva é importante para os líderes e gestores de recursos humanos que querem melhorar a sua inteligência emocional e o desempenho das suas equipes nesse sentido.

Palavras-chave: inteligência emocional, formação, competências, desempenho, aprendizagem, habilidades, liderança. 
Emotional intelligence is a fairly recent topic and consequently unexplored (Ashkanasy \& Dasborough, 2003). The discipline is so recent that even some scholars do not recognize its existence, as Antonakis, Ashkanasy, and Dasborough (2009) who present in their mail exchange: "one of the most confusing aspects of your argument is that, after maintaining that there is 'one intelligence', you then blithely go on to discuss two intelligences: crystalline and fluid". The history of emotions in labor goes back to Arlie Hoschschild (1983), who introduced the concept of emotional labor and emotional work. Many of the early advances in the field were not in the business area but in sociology. It was Goleman (1996) who initiated the wide spread interest on the field with his book Emotional Intelligence, in part, thanks to its publicity. There are several terms for the concept of Emotional Intelligence including emotional literacy, emotional quotient, and personal intelligences, among others (Dulewicz \& Higgs, 2000). It thus makes it difficult to present a unique definition for the concept. Goleman (1997b) taken from Dulewicz and Higgs (2000) presents an ample definition of the construct of emotional intelligence, which is about:

(a) Knowing what you are feeling and being able to handle those feelings without having them swamp you, (b) being able to motivate yourself to get jobs done, be creative and perform at your peak, (c) sensing what others are feeling, and handling relationships effectively. (Dulewicz \& Higgs, 2000, p. 342).

Martinez (1997, p. 72) taken from Dulewicz and Higgs (2000) defined social intelligence as "an array of non-cognitive skills, capabilities and competencies that influence a person's ability to cope with environmental demands and pressures". Mayer and Salovey (1997) defined it as comprising four branches: "It includes the abilities to accurately perceive emotions, to access and generate emotions so as to assist thought, to understand emotions and emotional knowledge, and to reflectively regulate emotions so as to promote emotional and intellectual growth", taken from Ashkanasy and Dasborough (2003, p. 5).

These definitions are particularly important for the development of this essay since the authors incorporate verbs that connote action such as being able, sensing, perceive, access, regulate, and generate. It suggests that emotional intelligence is not something that simply needs to be known. It implies, as Martinez(1997) stated, the acquisition of a set of capabilities and competencies.

When analyzing Mayer and Salovey (1997), the authors suggested a series of actions that insinuate the need for exercising Emotional Intelligence. Mayer, Salovey, Caruso, and Sitarenios (2003) have been developing and refining their ability test for Emotional Intelligence for more than a decade. Antonakis, et al. (2009) recognized it for its capacity to predict significant outcomes across diverse samples and different real world domains. The evaluation of Emotional Intelligence was not always that clear. Goleman (1996) proposed that success in life was a combination of $\mathrm{IQ}$ and Emotional Intelligence. IQ tests have been rather familiar but as Goleman stated, there is no pencil and paper test that can provide an Emotional Intelligence score and perhaps, there may not be one (Goleman, 1996). According to Dulewicz and Higgs (2000), Goleman's view of this evaluation was endorsed by authors like Steiner (1997). Nonetheless, Mayer and Salovey designed the MSCEIT with the objective of measuring four groups of Emotional Intelligence 
skills: (a) perceiving emotion accurately, (b) using emotion to facilitate thought, (c) understanding emotion, and (d) managing emotion (Mayer \& Salovey, 1997) taken from Mayer, et al. (2003). The evaluative capacities of the instrument are consistent with the definitions of the construct previously presented. Evaluating can be extremely valuable within a company for recruiting and promoting leaders, and useful for predicting their performance. In addition, it can highlight the areas where both, leaders and followers should improve in order to show better results. The problem is that test evaluation only provides a diagnosis about what is and is not working. It does not give any recipe for the improvement or development of the Emotional Intelligence competencies that need to be developed, not just learnt. Evaluating competencies is only one part of what organizations need to do in order to improve their leadership and performance. Learning and developing capabilities and competencies may be as important as training for a high performance athlete whose exams indicate low speed.

The study conducted by Ashkanasy and Dasborough (2003) at the University of Queensland suggests that learning and being interested on Emotional Intelligence seems to be very useful to predict performance: "it seems that student's understanding of the Emotional Intelligence Construct (as reflected in their examination question answer) predicted their team and individual performance in the Leadership Training Package" (Ashkanasy \& Dasborough, 2003, p. 20). The package is a 12000-word group project designed to demonstrate understanding of an undergraduate course called Leading and Managing People. Nonetheless, the authors ended up questioning whether Emotional Intelligence can be taught.
They indicated, "Students in leadership courses should be more than simply bystanders when studying the impact of emotions and Emotional Intelligence on performance". The suggestions made by Ashkanasy and Dasborough (2003) resonate with Höpfl \& Linstead (1997), taken form Dulewicz and Higgs (2000) when highlighting that children not only learn content, but they also learn about valuing their work, relating to peers and how to feel towards their fellows and teachers. The previous statement suggested that the learning process involves more than content. Being aware of how leaders need to manage emotions is part of the process of developing Emotional Intelligence competencies. However, something else may be needed. Acquiring Emotional Intelligence competencies is not a process that can be made by revising content. Performance requires other components; some of them would perhaps need to be learnt by practice.

Early on, when talking about Emotional Intelligence tests, Goleman (1996) suggested that the best way to test its components is by sampling a person's actual ability. Eventually, Emotional Intelligence can be evaluated by applying the MSCEIT test, however, Goleman's suggestion can provide an indication of how Emotional Intelligence competencies and capabilities can be learnt and developed. Sampling situations where leaders can actually be confronted with a situation obliging them to hide their own moods, focus on results despite distractors, express their feelings, delay gratification or sense what others are feeling, may result more efficient than simply being aware of them.

It is important to notice that this article does not suggest the elimination of the content component of the learning 
process but rather complementing it with training, in order to actually develop Emotional Intelligence capabilities and competencies. Competency standards have been defined as "agreed professional standards that are measurable, allowing student behavior to be observed and assessed while specific workplace tasks and roles are performed" (Cairns, 2000) taken from O'Connell, Gardner, and Coyer (2014, p. 2729). In their article, Phelps, Hase and Ellis (2005) presented a new model for computer education in which the authors acknowledged the broadly recognition of the competencies for being useful and necessary for the definition and education of practicebased professions.

Additionally, the authors recognized that the competencies are designed for practice in stable environments with familiar problems. In careers like nursing, the use of the term 'competency' is sometimes associated with the Vocational Educational and Training sector (Chiarella, Thoms, Lau, \& McInnes, 2008), and jobs with low requirements of critical thinking (Watson, Stimpson, Topping, \& Porock, 2002). This is definitely not the case of business. Leading a corporation does confront employees and managers with challenges that require more than a manual competence. However, critical thinking as seen at a school or college classroom is not either what adult leaders may need. As Brookfield stated, "there is no clear evidence that any of the skills of critical thinking learned in schools and colleges have much transferability to the context of adult life" (Brookfield, 1987, p. 380). In real life, leaders are less confronted with tests and assignments that evaluate their critical thinking in an academic manner. They frequently need to face situations where negotiations take place, consensus need to be built, stress needs be tolerated or decisions need to be made. In addition, just like nurses, leaders could be confronted with "work in environments and roles that are dynamic and unpredictable, necessitating attributes and skills to practice at advanced and extended levels in both familiar and unfamiliar [clinical] situations" (O'Connell, Gardner, \& Coyer, 2014). Since many of these traits cannot be learnt in a traditional academic environment, the idea of developing Emotional Intelligence capabilities may arise as a solution for Organizational Leaders. Cairns (2000) described capable people as "being creative, possessing a high degree of selfefficacy, knowing how to learn, being able of taking appropriate and effective action to formulate and solve problems, capable of applying competencies in unfamiliar and familiar situations, and being good team members". Capability is conceptualized as a continuous moving from the familiar to the unfamiliar (Stephenson \& Weil, 1992). This suggests that leaders need to be trained to deal with change and unpredictability. O'Connell, et al. (2014) stated:

Familiar workplace problems and contexts are the sphere where most people operate for much of the time, familiar problems with familiar solutions. Moving towards less familiar context or problems, capable people rely on the ability to formulate and devise solutions in unfamiliar situations by trusting intuition, judgement, the ability to solve problems and by using acquired knowledge and skills in new ways. Capability is a necessary part of specialist expertise and capable people continue to develop their specialist skills and knowledge long after they have left formal education. (O'Connell, et al., 2014, p. 2731). 
To be able to deal with complex situations, it is necessary for leadership training to embrace a new education framework that goes beyond theoretical knowledge. Leader training may need to confront leaders with real and symbolic challenges that strengthen their emotional intelligence and capabilities that are built on previous competencies. Challenges that, for example, help them to recognize and deal with their own fears in order to be able to take risks, one of the components that predicted advancement extremely well, according to what was found by Dulewicz and Higgs (2000). This new learning environment may resemble a training camp or an emergency room of a hospital rather than a traditional classroom; a learning environment where content is one of the components but not the only one.

\section{References}

Antonakis, J., Ashkanasy, N. M., \& Dasborough, M. T. (2009). Does leadership need emotional intelligence?. The Leadership Quarterly, 20(2), 247-261.

Ashkanasy, N. M., \& Dasborough, M. T. (2003). Emotional awareness and emotional intelligence in leadership teaching. Journal of Education for Business, 79(1), 18-22.

Brookfield, S. D. (1987). Developing Critical Thinkers: Challenging Adults to Explore Alternative Ways of Thinking and Acting. San Francisco: Jossey-Bass.

Cairns L. (2000) The process/outcome Approach to Becoming a Capable Organisation. Australian Capability Network Conference. Sydney, pp. 1-14.
Chiarella, M., Thoms D., Lau, C., \& Mclnnes, E. (2008). An overview of the competency movement in nursing and midwifery. Collegian, 15(2), 45-53.

Dulewicz, V., \& Higgs, M. (2000). Emotional intelligence-A review and evaluation study. Journal of Managerial Psychology, 15(4), 341372.

Goleman, D. (1996). Emotional Intelligence. Why It Can Matter More than IQ. Learning, 24(6), 49-50.

Goleman, D. (1997). Beyond IQ: developing the leadership competencies of emotional intelligence. Paper presented at the 2nd International Competency Conference, London.

Hochschild, A. (1983). The managed heart: Commercialization of human feeling. Berkeley: University of California Press.

Höpfl, H., \& Linstead, S. (1997). Introduction Learning to Feel and Feeling to Learn: Emotion and Learning in Organizations. Management Learning, 28(1), 5-12.

Martinez, M. (1997), The smarts that count. HR Magazine, 42(11), $72-$ 80.

Mayer, J.D. \& Salovey, P. (1997). What is emotional intelligence? In P. Salovey and D. Sluyter (eds.): Emotional development and emotional intelligence: educational implications, 3-31. New York: Basic Books.

Mayer, J. D., Salovey, P., Caruso, D. R., \& Sitarenios, G. (2003). Measuring emotional intelligence with the MSCEIT V2. 0. Emotion, 3(1), 97. 
O'Connell, J., Gardner, G., \& Coyer, F. (2014). Beyond competencies: using a capability framework in developing practice standards for advanced practice nursing. Journal of Advanced Nursing, 70(12), 2728-2735. doi:10.1111/jan.12475

Phelps, R., Hase, S., \& Ellis, A. (2005). Competency, capability, complexity and computers: exploring a new model for conceptualising end-user computer education. British Journa of Educational Technology, 36(1), 67-84.
Steiner, C. (1997) Achieving Emotional Literacy, London: Bloomsbury Publishing.

Stephenson, J., \& Weil, S. (1992). Quality in Learning; A Capability Approach in Higher Education. London: Kogan Page.

Watson, R., Stimpson, A., Topping, A., \& Porock, D. (2002). Clinical competence assessment in nursing: a systematic review of the literature. Journal of Advanced Nursing, 39(5), 421-431. 